\title{
Pharmacology of Antihistamines
}

\author{
Diana S. Church, MD, and Martin K. Church, PhD, DSc
}

\begin{abstract}
This article reviews the molecular biology of the interaction of histamine with its $\mathrm{H}_{1}$-receptor and describes the concept that $\mathrm{H}_{1}$-antihistamines are not receptor antagonists but are inverse agonists i.e. they produce the opposite effect on the receptor to histamine. It then discourages the use of first-generation $\mathrm{H}_{1}$-antihistamines in clinical practice today for two main reasons. First, they are less effective than second generation $\mathrm{H}_{1}$-antihistamines. Second, they have unwanted side effects, particularly central nervous system and anti-cholinergic effects, and have the potential for causing severe toxic reactions which are not shared by second-generation $\mathrm{H}_{1}$ antihistamines. There are many efficacious and safe second-generation $\mathrm{H}_{1}$-antihistamines on the market for the treatment of allergic disease. Of the three drugs highlighted in this review, levocetirizine and fexofenadine are the most efficacious in humans in vivo. However, levocetirizine may cause somnolence in susceptible individuals while fexofenadine has a relatively short duration of action requiring twice daily administration for full all round daily protection. While desloratadine is less efficacious, it has the advantages of rarely causing somnolence and having a long duration of action. Lastly, all $\mathrm{H}_{1}$-antihistamines have anti-inflammatory effects but it requires regular daily dosing rather than dosing 'on-demand' for this effect to be clinically demonstrable.
\end{abstract}

Key Words: $\mathrm{H}_{1}$-antihistamines, cetirizine, levocetirizine, fexofenadine, loratadine, desloratadine

(WAO Journal 2011; 4:S22-S27)

I $\mathrm{t}$ is now more than a century since the discovery of histamine, ${ }^{1}$ more than 70 years since the pioneering studies of Anne Marie Staub and Daniel Bovet led to the discovery of the first antihistamine ${ }^{2}$ and more than 60 years since the introduction into the clinic of antergan in $1942,{ }^{3}$ followed by diphenhydramine in $1945^{4}$ and chlorpheniramine, brompheniramine, and promethazine later the same decade. Medicinal chemistry was very different in those days compared with the present day as elegantly described by Emanuel in his review entitled "Histamine and the antiallergic antihistamines: a history of their discoveries." 5 The usual way of testing novel

From the University of Southampton School of Medicine, Southampton, UK; Allergie-Centrum-Charité/ECARF, Charité-Universitätsmedizin, Berlin, Germany.

Correspondence to: Martin K. Church, PhD, DSc, Sir Henry Wellcome Laboratories, South Block 825, Southampton General Hospital, Southampton SO16 6YD, United Kingdom.

Telephone: 44 (0)23 8079 6149. Fax: 44(0)23 8070 4183. E-mail: mkc@ southampton.ac.uk.

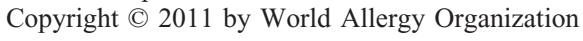

compounds was to measure histamine-induced contractions of pieces of muscle from experimental animals, usually guinea-pig intestine, suspended in an organ bath. Candidate antihistaminic compounds were primarily modifications of those synthesized as cholinergic antagonists and are from diverse chemical entities, ethanolamines, ethylene diamines, alkylamines, piperazines, piperidines, and phenothiazines. It is hardly surprising, therefore, that these first-generation antihistamines had poor receptor selectivity and significant unwanted side effects.

During this time, knowledge of the nature and diversity of receptors was rudimentary to say the least and it was only several decades later that the existence of more than one species of histamine receptor was discovered. This review will concentrate on the histamine $\mathrm{H}_{1}$-receptor. Further details on the biology and clinical functions of histamine $\mathrm{H}_{2^{-}}, \mathrm{H}_{3^{-}}$, and $\mathrm{H}_{4}$-receptors are the subject of a separate review. ${ }^{6}$

\section{THE HISTAMINE $\mathrm{H}_{\mathbf{1}}$-RECEPTOR}

The human histamine $\mathrm{H}_{1}$-receptor is a member of the superfamily of G-protein coupled receptors. This superfamily represents at least 500 individual membrane proteins that share a common structural motif of 7 transmembrane $\alpha$-helical segments 7,8 (Fig. 1A). The histamine $\mathrm{H}_{1}$-receptor gene encodes a 487 amino acid protein with a molecular mass of $55.8 \mathrm{kDa} .{ }^{9,10}$ The absence of introns in the $\mathrm{H}_{1}$-receptor gene indicates that only a single receptor protein is transcribed with no splice variants. ${ }^{10}$

The histamine $\mathrm{H}_{1}$-receptor, like other G-protein coupled receptors, may be viewed as "cellular switches," which exist as an equilibrium between the inactive or "off" state and the active or "on" state. ${ }^{11}$ In the case of the histamine $\mathrm{H}_{1}$-receptor, histamine cross-links sites on transmembrane domains III and $\mathrm{V}$ to stabilize the receptor in its active conformation, thus causing the equilibrium to swing to the on position $^{12}$ (Fig. 1B). $\mathrm{H}_{1}$-antihistamines, which are not structurally related to histamine, do not antagonize the binding of histamine but bind to different sites on the receptor to produce the opposite effect. For example, cetirizine crosslinks sites on transmembrane domains IV and VI to stabilize the receptor in the inactive state and swing the equilibrium to the off position ${ }^{13}$ (Fig. 1C). Thus, $\mathrm{H}_{1}$-antihistamines are not receptor antagonists but are inverse agonists in that they produce the opposite effect on the receptor to histamine. ${ }^{14}$ Consequently, the preferred term to define these drugs is " $\mathrm{H}_{1}$-antihistamines" rather than "histamine antagonists." 


\section{A Histamine $\mathrm{H}_{1}$-Receptor (GPCR)}

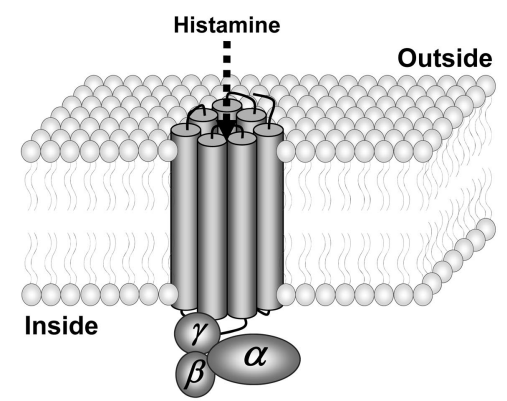

B Active Receptor C Inactive Receptor
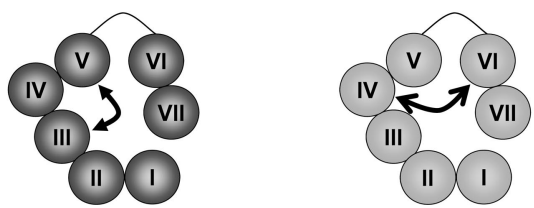

FIGURE 1. A, Diagram of a histamine $\mathrm{H}_{1}$-receptor in a membrane showing the 7 transmembrane domains. Histamine stimulates the receptor after its penetration into the central core of the receptor. B, A surface view of an activated receptor with histamine linking domains III and V. C, A surface view of an inactive receptor with cetirizine linking domains IV and VI.

\section{FIRST-GENERATION $\mathrm{H}_{\mathbf{1}}$-ANTIHISTAMINES}

Because first-generation $\mathrm{H}_{1}$-antihistamines derive from the same chemical stem from which cholinergic muscarinic antagonists, tranquilizers, antipsychotics, and antihypertensive agents were also developed, they have poor receptor selectivity and often interact with receptors of other biologically active amines causing antimuscarinic, anti- $\alpha$-adrenergic, and antiserotonin effects. But perhaps their greatest drawback is their ability to cross the blood-brain barrier and interfere with histaminergic transmission. Histamine is an important neuromediator in the human brain which contains approximately 64,000 histamine-producing neurones, located in the tuberomamillary nucleus. When activated, these neurones stimulate $\mathrm{H}_{1}$-receptors in all of the major parts of the cerebrum, cerebellum, posterior pituitary, and spinal cord ${ }^{15}$ where they increase arousal in the circadian sleep/wake cycle, reinforce learning and memory, and have roles in fluid balance, suppression of feeding, control of body temperature, control of the cardiovascular system, and mediation of stresstriggered release of adrenocorticotrophic hormone and $\beta$ endorphin from the pituitary gland. ${ }^{16}$ It is not surprising then that antihistamines crossing the blood-brain barrier interfere with all of these processes.

Physiologically, the release of histamine during the day causes arousal whereas its decreased production at night results in a passive reduction of the arousal response. When taken during the day, first-generation $\mathrm{H}_{1}$-antihistamines, even in the manufacturers' recommended doses, frequently cause daytime somnolence, sedation, drowsiness, fatigue, and impaired concentration and memory. ${ }^{17,18}$ When taken at night, first-generation $\mathrm{H}_{1}$-antihistamines increase the latency to the onset of rapid eye movement sleep and reduce the duration of rapid eye movement sleep. ${ }^{19-21}$ The residual effects of poor sleep, including impairment of attention, vigilance, working memory, and sensory-motor performance, are still present the next morning. ${ }^{20,22}$ The detrimental central nervous system effects of first-generation $\mathrm{H}_{1}$-antihistamines on learning and examination performance in children and on impairment of the ability of adults to work, drive, and fly aircraft have been reviewed in detail in a recent review. ${ }^{23}$

The use of first-generation $\mathrm{H}_{1}$-antihistamines in young children has recently been brought into question. In the United States, reports of serious and often life-threatening adverse events of promethazine in children led to a "boxed warning" being added in 2004 to the labeling of promethazine. The warning included a contraindication for use in children younger than 2 years and a strengthened warning with regard to use in children 2 years of age or older. ${ }^{24}$ In February 2009, the Medicines and Healthcare products Regulatory Agency (MHRA) in the United Kingdom ${ }^{25}$ advised that cough and cold remedies containing certain ingredients, including first-generation $\mathrm{H}_{1}$-antihistamines, should no longer be used in children younger than 6 years because the balance of benefit and risks has not been shown to be favorable. Reports submitted to regulators stated that more than 3000 people have reported adverse reactions to these drugs and that diphenhydramine and chlorpheniramine were mentioned in reports of 27 and 11 deaths, respectively. ${ }^{25}$

\section{SECOND-GENERATION $\mathrm{H}_{1}$-ANTIHISTAMINES}

A major advance in antihistamine development occurred in the 1980s with the introduction of second-generation $\mathrm{H}_{1}$-antihistamines, ${ }^{26}$ which are minimally sedating or nonsedating because of their limited penetration of the bloodbrain barrier. In addition, these drugs are highly selective for the histamine $\mathrm{H}_{1}$-receptor and have no anticholinergic effects.

When choosing an $\mathrm{H}_{1}$-antihistamine, patients seek attributes that include good efficacy, a rapid onset of action, a long duration of action, and freedom from unwanted effects. Although some of these attributes may be predicted from preclinical and pharmacokinetic studies, it is only in the clinical environment that they may be definitively established.

\section{Efficacy}

The efficacy of an $\mathrm{H}_{1}$-antihistamine is determined by 2 factors: the affinity of the drug for $\mathrm{H}_{1}$-receptors (absolute potency) and the concentration of the drug at the sites of the $\mathrm{H}_{1}$-receptors.

The affinity of an $\mathrm{H}_{1}$-antihistamine for $\mathrm{H}_{1}$-receptors is determined in preclinical studies. Desloratadine is the most potent antihistamine ( $\mathrm{Ki} 0.4 \mathrm{nM}$ ) followed by levocetirizine (Ki $3 \mathrm{nM}$ ) and fexofenadine (Ki $10 \mathrm{nM}$ ) (the lower the concentration, the higher potency). Although these are often considered to be fixed values, they may be influenced by temperature and $\mathrm{pH}$, and therefore, they can differ in physiologic and pathologic conditions. For example, in inflammation the $\mathrm{pH}$ of the tissues is reduced ${ }^{27}$ from 7.4 to 5.8 , leading to a 2 - to 5 -fold increase in the affinity of fexofenadine and 


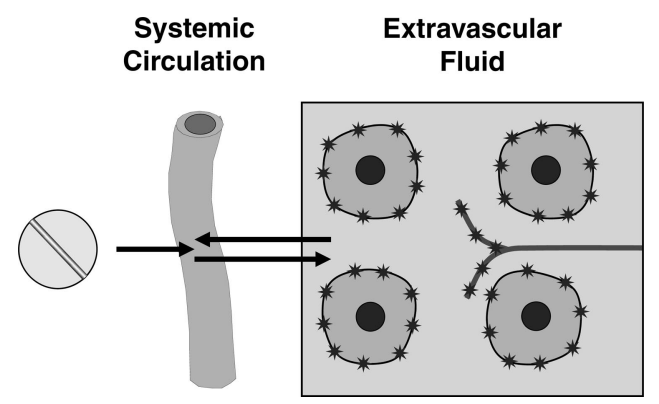

FIGURE 2. Diagrammatic representation of the absorption of an $\mathrm{H}_{1}$-antihistamine. Histamine $\mathrm{H}_{1}$-receptors are indicated by stars on the surface of cells and a sensory nerve in the extravascular space.

levocetirizine for $\mathrm{H}_{1}$-receptors but no change in the affinity of desloratadine. ${ }^{28}$

As shown in Figure 2, histamine receptors are situated on the cellular membranes of cells, including vascular and airways smooth muscle, mucous glands, and sensory nerves, all of which are surrounded by the extracellular fluid. Many factors affect concentration of free drug in this compartment. First, it must be absorbed into the systemic circulation after oral dosage with a tablet or capsule. Most $\mathrm{H}_{1}$-antihistamines are well absorbed, the exception being fexofenadine, which has a very variable absorption because of the influence of active transporting proteins as described later. ${ }^{29,30}$ Second is the extent of plasma binding which, with $\mathrm{H}_{1}$-antihistamines, is high, varying from $\sim 65 \%$ with desloratadine to $\sim 90 \%$ for levocetirizine. ${ }^{31}$ Third, and probably most influential, is the apparent volume of distribution which determines the plasma concentration of a drug after complete body distribution. The apparent volume of distribution is limited for levocetirizine $(0.4 \mathrm{~L} / \mathrm{kg})$, larger for fexofenadine $(5.4-5.8 \mathrm{~L} / \mathrm{kg})$, and particularly large for desloratadine $(\sim 49 \mathrm{~L} / \mathrm{kg}))^{32}$ The large apparent volume of distribution of desloratadine is largely due to its extensive intracellular uptake. In the study of Gillard and colleagues, ${ }^{31}$ the 4-hour plasma concentrations of levocetirizine, desloratadine, and fexofenadine are 28,1 , and $174 \mathrm{nM}$, respectively.

Because data on the concentrations of $\mathrm{H}_{1}$-antihistamines in relevant extracellular fluids is generally lacking, the best indirect estimate of efficacy is obtained by calculating receptor occupancy from knowledge of absolute potency and peak drug concentrations in the plasma, usually at $\sim 4$ hours after a single oral dose using the following equation. ${ }^{31}$

$$
\text { Receptor occupancy }(\%)=\mathrm{B}_{\max } \times \frac{\mathrm{L}}{\mathrm{L}+\mathrm{Ki}}
$$

where $B_{\max }$ is the maximal number of binding sites (set to $100 \%), L$ the concentration of free drug in the plasma, and $\mathrm{Ki}$ the equilibrium inhibition constant ( $\equiv$ absolute potency).

Thus, the calculation of receptor occupancy after single oral doses of drug shows values of $95 \%, 90 \%$, and $71 \%$ for fexofenadine, levocetirizine, and desloratadine, respectively, indicating that they are all very effective $\mathrm{H}_{1}$-antihistamines. Although receptor occupancy for these drugs appears to

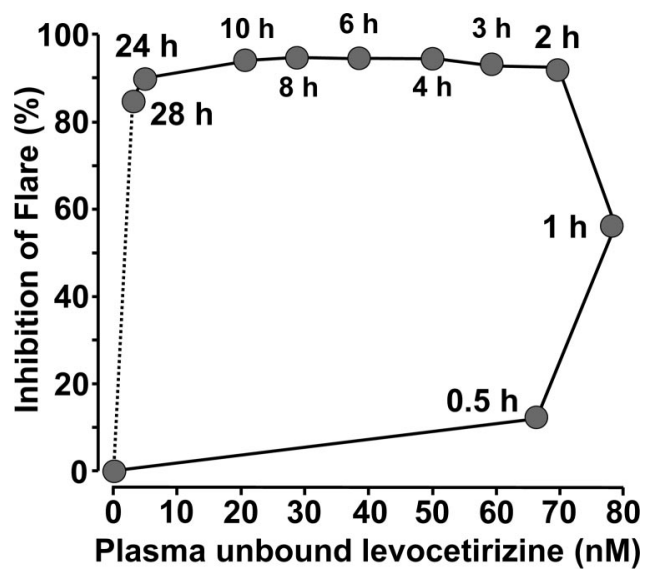

FIGURE 3. Hysteresis loop of the inhibition of the histamine-induced flare response plotted against the plasma concentration of unbound levocetirizine after administration of a single 5-mg dose to children. Redrawn from Ref. 39.

correlate with pharmacodynamic activity in skin wheal and flare studies and with efficacy in allergen challenge chamber studies, ${ }^{33,34}$ are the differences relevant in clinical practice? Studies in allergic rhinitis suggest that the above 3 drugs are of similar effectiveness. ${ }^{35,36}$ However, in chronic urticaria in which local histamine concentrations are high, the differences do seem to be important. For example, in head to head studies in this condition levocetirizine appears significantly more effective than desloratadine. ${ }^{37,38}$

\section{Speed of Onset of Action}

The speed of onset of action of a drug is often equated to the rate of its oral absorption. However, this is not strictly correct as seen from Figure 3, which shows the inhibition of the histamine-induced flare response (indicative of the prevention by levocetirizine of sensory neurone stimulation in the extravascular space) plotted against the concentration of free drug in the plasma. In this study in children, ${ }^{39}$ plasma concentrations of drug are near maximum by 30 minutes and yet it takes an additional 1.5 hours for the drug to diffuse into the extravascular space to produce a maximal clinical effect. In adults, the maximal inhibition of the flare response is usually $\sim 4$ hours for levocetirizine, fexofenadine, and desloratadine $^{40-42}$ but may be longer for drugs, such as loratadine and ebastine, which require metabolism to produce their active moiety. ${ }^{40}$

\section{Duration of Action}

Figure 3 also shows that the duration of action of levocetirizine in inhibiting the histamine-induced flare response is also much longer than would be predicted from a knowledge of its plasma concentration. ${ }^{39}$ This is presumably due to "trapping" of the drug by its strong and long-lasting binding to histamine $\mathrm{H}_{1}$-receptors. ${ }^{13}$ Although less active in the wheal and flare test, desloratadine has a similarly long duration of action. ${ }^{41}$ However, the duration of action of fexofenadine, calculated in the study of Purohit et $\mathrm{al}^{43}$ as the time for the wheal to be inhibited by at least $70 \%$, is less prolonged, being 8.5 hours for $120 \mathrm{mg}$ fexofenadine com- 
pared with 19 hours for cetirizine. The primary reason for the shorter duration of action of fexofenadine is that it is actively secreted into the intestine and urine. ${ }^{44}$

\section{Anti-Inflammatory Effects}

Although the majority of research into $\mathrm{H}_{1}$-antihistamines has focused on the histamine-dependent early phase symptoms of the allergic response, it is now becoming clear that these drugs have anti-inflammatory effects. This follows the observation by Bakker and colleagues ${ }^{45}$ that histamine can activate NF- $\kappa \mathrm{B}$, a transcription factor involved in the synthesis of many pro-inflammatory cytokines and adhesion molecules involved in the initiation and maintenance of allergic inflammation. The anti-inflammatory effects of $\mathrm{H}_{1}$ antihistamines, which is a class effect mediated through the $\mathrm{H}_{1}$-receptor, are summarized in Ref. ${ }^{14}$ The clinical implications of this lie in the ability of $\mathrm{H}_{1}$-antihistamines to reduce nasal congestion and hyper-reactivity, ${ }^{36}$ which result from the sensitization of sensory neurones in the nose by allergic inflammation. ${ }^{46}$ However, as nasal congestion is more slowly relieved than other nasal symptoms, ${ }^{47}$ continuous rather than on demand therapy with antihistamines is required for its treatment. ${ }^{48}$

\section{Elimination}

The metabolism and elimination of $\mathrm{H}_{1}$-antihistamines have been extensively reviewed elsewhere ${ }^{32,49}$ and will be only briefly summarized here. Cetirizine and levocetirizine are not metabolized and are excreted primarily unchanged in the urine. ${ }^{32}$ Desloratadine undergoes extensive metabolism in the liver. Although this gives the potential for drug-drug interactions, no significant interactions have been reported. ${ }^{49}$ Fexofenadine, which is also minimally metabolized, is excreted primarily in the feces after its active secretion into the intestine under the influence of active drug-transporting molecules. ${ }^{49}$ This gives the potential for interactions with agents such as grapefruit juice and St Johns Wort, which inhibit these transporters. Although plasma concentrations of fexofenadine may be increased by these agents, no significant resulting adverse reactions have been reported. ${ }^{49}$

\section{Unwanted Effects}

\section{Somnolence}

A major reason for the reduced penetration of secondgeneration $\mathrm{H}_{1}$-antihistamines into the brain is because their translocation across the blood-brain barrier is under the control of active transporter proteins, of which the ATP-dependent efflux pump, P-glycoprotein, is the best known. ${ }^{50,51}$ It also became apparent that antihistamines differ in their substrate specificity for P-glycoprotein, fexofenadine being a particularly good substrate. ${ }^{52}$ In the brain, the $\mathrm{H}_{1}$-receptor occupancy of fexofenadine assessed using positron emission tomography scanning is negligible, $<0.1 \%$, and, in psychomotor tests, fexofenadine is not significantly different from placebo. ${ }^{53}$ Furthermore, fexofenadine has been shown to be devoid of central nervous effects even at supraclinical doses, up to $360 \mathrm{mg} .{ }^{54}$

Although fexofenadine is devoid of CNS effects, other second-generation $\mathrm{H}_{1}$-antihistamines many still penetrate the brain to a small extent where they have the potential to cause some degree of drowsiness or somnolence, particularly when used in higher doses. For example, positron emission tomography scanning of the human brain has shown that single oral doses of 10 and $20 \mathrm{mg}$ of cetirizine caused 12.5 and $25.2 \%$ occupancy of the $\mathrm{H}_{1}$-receptors in prefrontal and cingulate cortices, respectively. ${ }^{55}$ These results would explain the repeated clinical findings that the incidence of drowsiness or fatigue is greater with cetirizine than with placebo. ${ }^{56-59}$ Recent publications have suggested that, at manufacturer's recommended doses, levocetirizine is less sedating than cetirizine $^{60}$ and desloratadine causes negligible somnolence. ${ }^{49,61}$ However, it should be pointed out that "mean results" do not reveal everything as some patients may show considerable somnolence whereas others are unaffected.

\section{Cardiotoxicity}

The propensity of astemizole and terfenadine to block the $\mathrm{I}_{\mathrm{Kr}}$ current, to prolong the QT interval, and to potentially cause serious polymorphic ventricular arrhythmias such as torsades de pointes is well documented. ${ }^{14,62}$ These 2 drugs are no longer approved by regulatory agencies in most countries. In addition, some first-generation $\mathrm{H}_{1}$-antihistamines, such as promethazine, ${ }^{63}$ brompheniramine, ${ }^{64}$ and diphenhydramine, ${ }^{65}$ may also be associated with a prolonged QTc and cardiac arrhythmias when taken in large doses or overdoses. No clinically significant cardiac effects have been reported for the second-generation $\mathrm{H}_{1}$-antihistamines loratadine, fexofenadine, mizolastine, ebastine, azelastine, cetirizine, desloratadine, and levocetirizine. ${ }^{66-69}$

\section{CONCLUSIONS}

In conclusion, the use of first-generation $\mathrm{H}_{1}$-antihistamines should be discouraged in clinical practice today for 2 main reasons. First, they are less effective than secondgeneration $\mathrm{H}_{1}$-antihistamines. ${ }^{17,70,71}$ Second, they have unwanted side effects and the potential for causing severe toxic reactions which are not shared by second-generation $\mathrm{H}_{1}$ antihistamines. With regard to second-generation $\mathrm{H}_{1}$-antihistamines, there are many efficacious and safe drugs on the market for the treatment of allergic disease. Of the 3 drugs highlighted in this review, levocetirizine and fexofenadine are the most potent in humans in vivo. However, levocetirizine may cause somnolence in susceptible individuals whereas fexofenadine has a relatively short duration of action and may be required to be given twice daily for all-round daily protection. Although desloratadine is less potent, it has the advantages of rarely causing somnolence and having a long duration of action. Lastly, all $\mathrm{H}_{1}$-antihistamines have anti-inflammatory effects but it requires regular daily dosing rather than dosing "on demand" for this action to be clinically demonstrable.

\section{ACKNOWLEDGMENTS}

The contents of this article were presented as an invited World Allergy Organization Lecture at the First Middle East Asia Allergy Asthma and Immunology Congress (MEAAAIC) in Dubai, UAE, March 26-29, 2009, as part of the symposium, "Treatment of Chronic Allergies."

$U C B$ provided an educational grant for the symposium. 


\section{REFERENCES}

1. Windaus A, Vogt W. Synthese des imidazolylathylamins. Ber Dtsch Chem Ges. 1907;3:3691-3695.

2. Staub AM, Bovet D. Action de la thymoxyethyldiethylamine (929F) et des ethers phenoliques sur le choc anaphylactique. Compt Rend Soc Biol. 1937; $125: 818-821$.

3. Halpern BN. Les antihistaminiques desynthese. Essais de chemotherapie des etats allergiques. Arch Int Pharmacodyn Ther. 1942;681: 339-408.

4. Loew ER, Macmillan R, Kaiser M. The antihistamine properties of benadryl, B dimethylaminoethyl benzhydryl ether hydrochloride. J Pharmacol Exp Ther. 1946;86:229-238.

5. Emanuel MB. Histamine and the antiallergic antihistamines: a history of their discoveries. Clin Exp Allergy. 1999;29 Suppl 3:1-11.

6. Church MK. Histamine and its receptors. In: Pawankar R, Holgate ST, Rosenwasser LJ, eds. Allergy Frontiers: Volume 2; Classification and Pathomechanisms. Tokyo: Springer; 2009:329-356.

7. Leurs R, Watanabe T, Timmerman H. Histamine receptors are finally 'coming out.' Trends Pharmacol Sci. 2001;22:337-339.

8. Hill SJ. G-protein-coupled receptors: past, present and future. $\mathrm{Br} J$ Pharmacol. 2006;147 Suppl 1:S27-S37.

9. Fukui H, Fujimoto K, Mizuguchi H, Sakamoto K, Horio Y, et al. Molecular cloning of the human histamine $\mathrm{H} 1$ receptor gene. Biochem Biophys Res Commun. 1994;201:894-901.

10. De Backer MD, Loonen I, Verhasselt P, Neefs JM, Luyten WH. Structure of the human histamine H1 receptor gene. Biochem J. 1998; 335(Pt 3):663-670.

11. McCudden CR, Hains MD, Kimple RJ, Siderovski DP, Willard FS. G-protein signaling: back to the future. Cell Mol Life Sci. 2005;62(5): 551-577.

12. Wieland K, Laak AM, Smit MJ, Kühne R, Timmerman H, Leurs R. Mutational analysis of the antagonist-binding site of the histamine H-1 receptor. J Biol Chem. 1999;274:29994-30000.

13. Gillard M, Van Der Perren C, Moguilevsky N, Massingham R, Chatelain $\mathrm{P}$. Binding characteristics of cetirizine and levocetirizine to human $\mathrm{H}(1)$ histamine receptors: contribution of Lys(191) and Thr(194). Mol Pharmacol. 2002;61(2):391-399.

14. Leurs R, Church MK, Taglialatela M. H1-antihistamines: inverse agonism, anti-inflammatory actions and cardiac effects. Clin Exp Allergy. 2002;32(4):489-498.

15. Haas H, Panula P. The role of histamine and the tuberomamillary nucleus in the nervous system. Nat Rev Neurosci. 2003;4(2):121-130.

16. Brown RE, Stevens DR, Haas HL. The physiology of brain histamine. Prog Neurobiol. 2001;63(6):637-672.

17. Simons FE. Advances in H1-antihistamines. $N$ Engl J Med. 2004; 351(21):2203-2217.

18. Juniper EF, Stahl E, Doty RL, Simons FE, Allen DB, Howarth PH. Clinical outcomes and adverse effect monitoring in allergic rhinitis. J Allergy Clin Immunol. 2005;115(3 Suppl 1):S390-S413.

19. Adam K, Oswald I. The hypnotic effects of an antihistamine: promethazine. Br J Clin Pharmacol. 1986;22(6):715-717.

20. Boyle J, Eriksson M, Stanley N, Fujita T, Kumagi Y. Allergy medication in Japanese volunteers: treatment effect of single doses on nocturnal sleep architecture and next day residual effects. Curr Med Res Opin. 2006;22(7):1343-1351.

21. Rojas-Zamorano JA, Esqueda-Leon E, Jimenez-Anguiano A, CintraMcGlone L, Mendoza Melendez MA, Velazquez Moctezuma J. The H1 histamine receptor blocker, chlorpheniramine, completely prevents the increase in REM sleep induced by immobilization stress in rats. Pharmacol Biochem Behav. 2009;91(3):291-294.

22. Kay GG, Berman B, Mockoviak SH, Morris CE, Reeves D, et al. Initial and steady-state effects of diphenhydramine and loratadine on sedation, cognition, mood, and psychomotor performance. Arch Intern Med. 1997; 157(20):2350-2356.

23. Church MK, Maurer M, Simons EF, Bindslev-Jensen C, van Cuuwenberge $\mathrm{P}$, et al. Should first-generation $\mathrm{H}_{1}$-antihistamines still be available as over-the-counter medications? A GA ${ }^{2} \mathrm{LEN}$ task force report. Allergy. 2010;65:459-466.

24. Starke PR, Weaver J, Chowdhury BA. Boxed warning added to promethazine labeling for pediatric use. $N$ Engl J Med. 2005;352(25):2653.
25. Anon. Children's over-the-counter cough and cold medicines. 2009. Report No.: http://www.mhra.gov.uk/NewsCentre/Pressreleases/CON038902. Accessed October 2009.

26. Holgate ST, Canonica GW, Simons FE, Taglialatela M, Tharp M, Timmerman H, Yanai K. Consensus Group on New-Generation Antihistamines (CONGA): present status and recommendations. Clin Exp Allergy. 2003;33(9):1305-1324.

27. Hunt JF, Fang K, Malik R, Snyder A, Malhotra N, Platts-Mills TA, Gaston B. Endogenous airway acidification. Implications for asthma pathophysiology. Am J Respir Crit Care Med. 2000;161(3 Pt 1):694699.

28. Gillard M, Chatelain P. Changes in $\mathrm{pH}$ differently affect the binding properties of histamine H1 receptor antagonists. Eur J Pharmacol. 2006;530(3):205-214

29. Russell T, Stoltz M, Weir S. Pharmacokinetics, pharmacodynamics, and tolerance of single- and multiple-dose fexofenadine hydrochloride in healthy male volunteers. Clin Pharmacol Ther. 1998;64(6): 612-621.

30. Tannergren C, Petri N, Knutson L, Hedeland M, Bondesson U, Lennernäs H. Multiple transport mechanisms involved in the intestinal absorption and first-pass extraction of fexofenadine. Clin Pharmacol Ther. 2003;74(5):423-436.

31. Gillard M, Benedetti MS, Chatelain P, Baltes E. Histamine H1 receptor occupancy and pharmacodynamics of second generation H1-antihistamines. Inflamm Res. 2005;54(9):367-369.

32. Molimard M, Diquet B, Benedetti MS. Comparison of pharmacokinetics and metabolism of desloratadine, fexofenadine, levocetirizine and mizolastine in humans. Fundam Clin Pharmacol. 2004;18(4):399-411.

33. Popov TA, Dumitrascu D, Bachvarova A, Bocsan C, Dimitrov V, Church MK. A comparison of levocetirizine and desloratadine in the histamine-induced wheal and flare response in human skin in vivo. Inflamm Res. 2006;55(6):241-244.

34. Gillman S, Gillard M, Strolin Benedetti M. The concept of receptor occupancy to predict clinical efficacy: a comparison of second generation H1 antihistamines. Allergy Asthma Proc. 2009;30(4):366-376.

35. Berger WE, Lumry WR, Meltzer EO, Pearlman DS. Efficacy of desloratadine, $5 \mathrm{mg}$, compared with fexofenadine, $180 \mathrm{mg}$, in patients with symptomatic seasonal allergic rhinitis. Allergy Asthma Proc. 2006; 27(3):214-223.

36. Bachert C. A review of the efficacy of desloratadine, fexofenadine, and levocetirizine in the treatment of nasal congestion in patients with allergic rhinitis. Clin Ther. 2009;31(5):921-944.

37. Potter PC, Kapp A, Maurer M, Guillet G, Jian AM, Hauptmann P, Finlay AY. Comparison of the efficacy of levocetirizine $5 \mathrm{mg}$ and desloratadine $5 \mathrm{mg}$ in chronic idiopathic urticaria patients. Allergy. 2009;64(4):596604.

38. Staevska M, Popov TA, Kralimarkova T, Lazarova C, Kraeva S, et al The effectiveness of levocetirizine and desloratadine in up to 4 times conventional doses in difficult-to-treat urticaria. J Allergy Clin Immunol. 2010;125(3):676-682.

39. Simons KJ, Benedetti MS, Simons FE, Gillard M, Baltes E. Relevance of H1-receptor occupancy to H1-antihistamine dosing in children. J Allergy Clin Immunol. 2007;119(6):1551-1554.

40. Grant JA, Riethuisen JM, Moulaert B, DeVos C. A double-blind, randomized, single-dose, crossover comparison of levocetirizine with ebastine, fexofenadine, loratadine, mizolastine, and placebo: suppression of histamine-induced wheal-and-flare response during 24 hours in healthy male subjects. Ann Allergy Asthma Immunol. 2002;88(2):190-197.

41. Purohit A, Melac M, Pauli G, Frossard N. Twenty-four-hour activity and consistency of activity of levocetirizine and desloratadine in the skin. Br J Clin Pharmacol. 2003;56(4):388-394.

42. Purohit A, Melac M, Pauli G, Frossard N. Comparative activity of cetirizine and desloratadine on histamine-induced wheal-and-flare responses during 24 hours. Ann Allergy Asthma Immunol. 2004;92(6): 635-640.

43. Purohit A, Duvernelle C, Melac M, Pauli G, Frossard N. Twenty-four hours of activity of cetirizine and fexofenadine in the skin. Ann Allergy Asthma Immunol. 2001;86(4):387-392.

44. Miura M, Uno T. Clinical pharmacokinetics of fexofenadine enantiomers. Expert Opin Drug Metab Toxicol. 2010;6(1):69-74.

45. Bakker RA, Schoonus SB, Smit MJ, Timmerman H, Leurs R. Histamine $\mathrm{H}(1)$-receptor activation of nuclear factor-kappa B: roles for $\mathrm{G}$ beta 
gamma- and $\mathrm{G}$ alpha(q/11)-subunits in constitutive and agonist-mediated signaling. Mol Pharmacol. 2001;60(5):1133-1142.

46. Cheng J, Yang XN, Liu X, Zhang SP. Capsaicin for allergic rhinitis in adults. Cochrane Database Syst Rev. 2006;(2):CD004460.

47. Bachert C, Bousquet J, Canonica GW, Durham SR, Klimek L, et al. Levocetirizine improves quality of life and reduces costs in long-term management of persistent allergic rhinitis. J Allergy Clin Immunol. 2004;114(4):838-844.

48. Canonica GW, Fumagalli F, Guerra L, Baiardini I, Compalati E, et al. Levocetirizine in persistent allergic rhinitis: continuous or on-demand use? A pilot study. Curr Med Res Opin. 2008;24(10):2829-2839.

49. Devillier P, Roche N, Faisy C. Clinical pharmacokinetics and pharmacodynamics of desloratadine, fexofenadine and levocetirizine: a comparative review. Clin Pharmacokinet. 2008;47(4):217-230.

50. Schinkel AH. P-Glycoprotein, a gatekeeper in the blood-brain barrier. Adv Drug Deliv Rev. 1999;36(2-3):179-194.

51. Chen C, Hanson E, Watson JW, Lee JS. P-glycoprotein limits the brain penetration of nonsedating but not sedating H1-antagonists. Drug Metab Dispos. 2003;31(3):312-318.

52. Cvetkovic M, Leake B, Fromm MF, Wilkinson GR, Kim RB. OATP and P-glycoprotein transporters mediate the cellular uptake and excretion of fexofenadine. Drug Metab Dispos. 1999;27(8):866-871.

53. Tashiro M, Sakurada Y, Iwabuchi K, Mochizuki H, Kato M, et al. Central effects of fexofenadine and cetirizine: measurement of psychomotor performance, subjective sleepiness, and brain histamine H1receptor occupancy using 11C-doxepin positron emission tomography. $J$ Clin Pharmacol. 2004;44(8):890-900.

54. Hindmarch I, Shamsi Z, Kimber S. An evaluation of the effects of high-dose fexofenadine on the central nervous system: a double-blind, placebo-controlled study in healthy volunteers. Clin Exp Allergy. 2002; 32(1):133-139.

55. Tashiro M, Kato M, Miyake M, Watanuki S, Funaki Y, et al. Dose dependency of brain histamine $\mathrm{H} 1$ receptor occupancy following oral administration of cetirizine hydrochloride measured using PET with [(11)C]doxepin. Hum Psychopharmacol. 2009;24(7):540-548.

56. Meltzer EO, Weiler JM, Widlitz MD. Comparative outdoor study of the efficacy, onset and duration of action, and safety of cetirizine, loratadine, and placebo for seasonal allergic rhinitis. J Allergy Clin Immunol. 1996;97(2):617-626.

57. Howarth PH, Stern MA, Roi L, Reynolds R, Bousquet J. Doubleblind, placebo-controlled study comparing the efficacy and safety of fexofenadine hydrochloride (120 and $180 \mathrm{mg}$ once daily) and ceti- rizine in seasonal allergic rhinitis. J Allergy Clin Immunol. 1999; 104(5):927-933.

58. Salmun LM, Gates D, Scharf M, Greiding L, Ramon F, Heithoff K. Loratadine versus cetirizine: assessment of somnolence and motivation during the workday. Clin Ther. 2000;22(5):573-582.

59. Mann RD, Pearce GL, Dunn N, Shakir S. Sedation with "non-sedating" antihistamines: four prescription-event monitoring studies in general practice. BMJ. 2000;320(7243):1184-1186.

60. De Vos C, Mitchev K, Pinelli ME, Derde MP, Boev R. Non-interventional study comparing treatment satisfaction in patients treated with antihistamines. Clin Drug Investig. 2008;28(4):221-230.

61. Day JH, Briscoe MP, Rafeiro E, Ratz JD. Comparative clinical efficacy, onset and duration of action of levocetirizine and desloratadine for symptoms of seasonal allergic rhinitis in subjects evaluated in the Environmental Exposure Unit (EEU). Int J Clin Pract. 2004;58(2):109118.

62. Woosley RL. Cardiac actions of antihistamines. Annu Rev Pharmacol Toxicol. 1996;36:233-252.

63. Jo SH, Hong HK, Chong SH, Lee HS, Choe H. H(1) antihistamine drug promethazine directly blocks hERG $\mathrm{K}(+)$ channel. Pharmacol Res. 2009;60(5):429-437.

64. Park SJ, Kim KS, Kim EJ. Blockade of HERG K+ channel by an antihistamine drug brompheniramine requires the channel binding within the S6 residue Y652 and F656. J Appl Toxicol. 2008;28(2):104-111.

65. Zareba W, Moss AJ, Rosero SZ, Hajj-Ali R, Konecki J, Andrews M. Electrocardiographic findings in patients with diphenhydramine overdose. Am J Cardiol. 1997;80(9):1168-1173.

66. Ten Eick AP, Blumer JL, Reed MD. Safety of antihistamines in children. Drug Saf. 2001;24(2):119-147.

67. DuBuske LM. Second-generation antihistamines: the risk of ventricular arrhythmias. Clin Ther. 1999;21(2):281-295.

68. Simons FE, Prenner BM, Finn A Jr. Efficacy and safety of desloratadine in the treatment of perennial allergic rhinitis. J Allergy Clin Immunol. 2003;111(3):617-622.

69. Hulhoven R, Rosillon D, Letiexhe M, Meeus MA, Daoust A, Stockis A. Levocetirizine does not prolong the QT/QTc interval in healthy subjects: results from a thorough QT study. Eur J Clin Pharmacol. 2007;63(11): 1011-1017.

70. Simons FE. Comparative pharmacology of H1 antihistamines: clinical relevance. Am J Med. 2002;113 Suppl 9A:38S-46S.

71. Simons FE, Silver NA, Gu X, Simons KJ. Clinical pharmacology of H1-antihistamines in the skin. J Allergy Clin Immunol. 2002;110(5): $777-783$. 